\title{
CD4 Expressing Cell Count
}

National Cancer Institute

\section{Source}

National Cancer Institute. CD4 Expressing Cell Count. NCI Thesaurus. Code C103810.

The determination of the amount of the CD4 expressing cells in a sample. 